\title{
Biwalirudyna w roku 2014 - nowe dane, nowe spojrzenie
}

\author{
Dariusz Dudek \\ II Klinika Kardiologii, Instytut Kardiologii, Uniwersytet Jagielloński, Collegium Medicum, Kraków
}

Z całą pewnością należy docenić wysiłki Autorów stanowiska [1] mającego na celu sprecyzowanie miejsca biwalirudyny we współczesnej terapii ostrego zawału serca z uniesieniem odcinka ST (STEMI), chociaż w świetle najnowszych danych rola tego leku w terapii STEMI nie jest tak do końca jednoznaczna, jak to przedstawiono. Wyniki badania HORIZONS-AMI [2,3] potwierdziły przewagę biwalirudyny nad łącznym podaniem heparyny niefrakcjonowanej (UFH) i rutynowo dożylnego inhibitora receptora płytkowego glikoproteiny (GP) Ilb/IIla nie tylko w zakresie redukcji powikłań krwotocznych, ale także zmniejszenia śmiertelności krótkoterminowej i odległej wśród pacjentów z STEMI leczonych pierwotną przezskórną interwencją wieńcową (PCI). Tym samym — zgodnie z wytycznymi Europejskiego Towarzystwa Kardiologicznego dotyczącymi leczenia STEMI z 2012 r. — biwalirudyna stała się lekiem preferowanym w stosunku do połączenia UFH $\mathrm{i}$ inhibitora GP IIb/IIla [4]. Ponadto wyniki badania EUROMAX [5] potwierdziły bezpieczeństwo i skuteczność podania biwalirudyny przed transportem pacjentów z STEMI w celu wykonania pierwotnej PCI. W tym badaniu zastosowanie biwalirudyny wiązało się z redukcją dużych powikłań krwotocznych niezwiązanych z leczeniem kardiochirurgicznym oraz łącznego punktu końcowego obejmującego zgon i duże krwawienie. Jednak zarówno w badaniu HORIZONS-AMI [2], jak i EUROMAX [5] zanotowano zwiększone ryzyko ostrej zakrzepicy w stencie wśród pacjentów leczonych biwalirudyną. Ponadto, mimo włączenia do badania HORIZONS-AMI grupy chorych o stosunkowo niskim ryzyku powikłań niedokrwiennych, 7,2\% pacjentów stosujących biwalirudynę wymagało ratunkowego podania inhibitora GP IIb/IIla [2].

Z całą pewnością trudno zgodzić się z opinią Autorów stanowiska [1], że zakrzepica w stencie jest powikłaniem błahym. Jej wystąpienie często wiąże się ze zwiększeniem strefy zawału czy też pojawieniem się niestabilności hemodynamicznej, co może się wiązać z podwyższonym ryzykiem zgonu. Próbę zmniejszenia ryzyka wystąpienia ostrej zakrzepicy w stencie u osób leczonych biwalirudyną stanowi zastosowanie przedłużonego wlewu leku po zakończeniu
PCI. Jednak mimo użycia przedłużonego wlewu biwalirudyny w badaniu EUROMAX (22,5\% pacjentów - dawka pełna stosowana w trakcie $\mathrm{PCl} ; 77,5 \%$ pacjentów — dawka zredukowana) ryzyko ostrej zakrzepicy w stencie było podwyższone wśród osób leczonych biwalirudyną [5]. Istnieją sugestie, że to właśnie dawka pełna, odpowiadająca dawce stosowanej w trakcie $\mathrm{PCl}$, może być skuteczniejsza w zakresie redukcji ryzyka powikłań zakrzepowych niż dawka zredukowana, choć wymaga to potwierdzenia w kolejnych badaniach. Inną testowaną koncepcją była próba zmniejszenia ryzyka ostrej zakrzepicy w stencie u pacjentów leczonych biwalirudyną poprzez podanie nowych doustnych inhibitorów receptora płytkowego P2Y ${ }_{12}$ (prasugrel, tikagrelor). W badaniu BRAVE 4 [6], porównującym zastosowanie połączenia UFH i klopidogrelu w stosunku do połączenia biwalirudyny z prasugrelem, ryzyko zakrzepicy w stencie w okresie 30 dni kształtowało się na zbliżonym poziomie (brak danych dotyczących ostrej zakrzepicy w stencie). Jednak liczebność badanych grup nie była wystarczająco duża, by jednoznacznie wykluczyć lub potwierdzić ewentualne różnice w zakresie tego punktu końcowego. Ponadto przedstawione w trakcie Kongresu American College of Cardiology w marcu 2014 r. wyniki badania HEAT $\mathrm{PPCl}$, porównującego UFH z biwalirudyną (z możliwością ratunkowego podania inhibitora GP IIb/IIla w obu badanych grupach), potwierdziły zwiększone ryzyko ostrej zakrzepicy w stencie w grupie pacjentów z STEMI poddawanych pierwotnej PCI leczonych biwalirudyną - nawet w odniesieniu do samej UFH [7]. Co istotne, ponad 90\% chorych w obu badanych grupach było leczonych nowymi doustnymi lekami przeciwpłytkowymi. Podobnie były one stosowane u ok. $60 \%$ pacjentów włączonych do badania EUROMAX [5]. Tym samym zastosowanie prasugrelu czy tikagreloru, mimo ich potwierdzonej skuteczności klinicznej, może nie niwelować ryzyka wystąpienia ostrej zakrzepicy w stencie u pacjentów leczonych biwalirudyną. Jest to uzasadnione z patofizjologicznego punktu widzenia, gdyż nawet w przypadku tych leków, o szybkim i silnym efekcie przeciwpłytkowym, moment wystąpienia pełnego efektu działania może być opóźniony,

\footnotetext{
Adres do korespondencji:

prof. dr hab. n. med. Dariusz Dudek, II Klinika Kardiologii, Instytut Kardiologii, Uniwersytet Jagielloński, Collegium Medicum, ul. Kopernika 17, 31-501 Kraków, tel: +48 1242471 81, faks: +48124247184, e-mail: mcdudek@cyfronet.pl

Copyright (C) Polskie Towarzystwo Kardiologiczne
} 
szczególnie u pacjentów z STEMI i niestabilnością hemodynamiczną.

Należy zwrócić uwagę, że do badań HORIZONS-AMI [2] i EUROMAX [5] nie włączano osób charakteryzujących się potencjalnie najwyższym ryzykiem krwawień (z przeciwwskazaniami do zastosowania leków przeciwpłytkowych, w tym inhibitorów GP Ilb/IIla), a korzyść z użycia biwalirudyny w zakresie redukcji powikłań krwotocznych była jednoznacznie potwierdzona w porównaniu z osobami leczonymi kombinacją UFH i inhibitora GP IIb/Illa. Zarówno wyniki badania BRAVE 4 [6], jak i HEAT PPCI [7], porównujących biwalirudynę z UFH (bez rutynowego podania inhibitora GP Ilb/IIla), nie wykazały przewagi biwalirudyny w zakresie redukcji ryzyka krwawień. Tym samym biwalirudyna nie powinna być rekomendowana ściśle dla pacjentów z bardzo wysokim ryzykiem krwawień (jako alternatywa dla UFH czy kombinacji UFH i inhibitora GP IIb/IIla).

Warto podkreślić, że aktualna strategia leczenia STEMI w Polsce bardziej odpowiada konstrukcji badania HEAT PPCI (UFH z selektywnym podaniem inhibitora GP IIb/IIla, wysoki odsetek zastosowania dostępu promieniowego i nowych leków przeciwpłytkowych) niż HORIZONS-AMI (rutynowe podanie inhibitora GP Ilb/IIla). W 2012 r. w Polsce inhibitory GP IIb/IIla były stosowane u niespełna 30\% pacjentów leczonych z powodu ostrego zespołu wieńcowego [8]. Może to tym samym ograniczać zainteresowanie biwalirudyną, gdyż zgodnie z katalogiem Narodowego Funduszu Zdrowia biwalirudyna może być alternatywą dla zastosowania UFH w połączeniu z inhibitorem GP Ilb/Illa, gdy rozważa się jego podanie, ale należy się spodziewać zwiększonego ryzyka powikłań krwotocznych. W tym przypadku podanie biwalirudyny może pozwolić na uzyskanie niskiego ryzyka krwawień przy odpowiednim poziomie redukcji powikłań niedokrwiennych.

Konflikt interesów: granty na organizację konferencji z: Medicines Company, Lilly, AstraZeneca, Glaxo.

\section{Piśmiennictwo}

1. Wożakowska-Kapłon B, Lesiak M, Ochała M et al. Stanowisko grupy ekspertów Sekcji Farmakoterapii Sercowo-Naczyniowej i Asocjacji Interwencji Sercowo-Naczyniowych Polskiego Towarzystwa Kardiologicznego w sprawie stosowania biwalirudyny u pacjentów z ostrym zawałem serca poddawanych przezskórnej interwencji wieńcowej w Polsce. Kardiol Pol, 2014; 72: 761-765.

2. Stone GW, Witzenbichler B, Guagliumi G et al. Bivalirudin during primary PCI in acute myocardial infarction. N Engl J Med, 2008; 358: 2218-2230.

3. Mehran R, Lansky AJ, Witzenbichler B et al. Bivalirudin in patients undergoing primary angioplasty for acute myocardial infarction (HORIZONS-AMI): 1-year results of a randomised controlled trial. Lancet, 2009; 374: 1149-1159.

4. Steg PG, James SK, Atar D et al. ESC guidelines for the management of acute myocardial infarction in patients presenting with ST-segment elevation. Eur Heart J, 2012; 33: 2569-2619.

5. Steg PG, van't Hof A, Hamm CW et al. Bivalirudin started during emergency transport for primary PCI. N Engl J Med, 2013; 369: 2207-2217.

6. Schulz S, Richardt G, Laugwitz KL et al. Prasugrel plus bivalirudin vs. clopidogrel plus heparin in patients with ST-segment elevation myocardial infarction. Eur Heart J, 2014; May 9 [Epub ahead of print].

7. Shahzad A, Kemp I, Mars C et al. Unfractionated heparin versus bivalirudin in primary percutaneous coronary intervention (HEAT-PPCI): an open-label, single centre, randomised controlled trial. Lancet, 2014; Jul 4 [Epub ahead of print].

8. Dudek D, Legutko J, Siudak Z et al. [Interventional cardiology in Poland in the year 2012. Summary report of the Association of Cardiovascular Interventions of the Polish Cardiac Society]. Kardiol Pol, 2013; 71: 1213-1219. 